\title{
LESS ovariohysterectomy in cats using a new homemade multiport
}

\author{
Diego da Costa $^{1}$ Renato do Nascimento Libardoni ${ }^{1}$ Júlia Tramontini Schmitt ${ }^{1}$ \\ Aline Spode Padilha ${ }^{1}$ Francisco Jorge Schulz Júnior ${ }^{1}$ Michelli Westphal de Ataíde ${ }^{1}$ \\ Felipe Barreto Menezes ${ }^{1}$ Karina Allievi $^{2}$ Mauricio Veloso Brun ${ }^{3}$ \\ Pedro Paulo Maia Teixeira ${ }^{4}$ Marco Augusto Machado Silva ${ }^{*}$
}

\author{
${ }^{1}$ Hospital Veterinário, Faculdade de Agronomia e Medicina Veterinária, Universidade de Passo Fundo (UPF), 99.052-900, Passo Fundo, RS, \\ Brasil. E-mail: silvamam@gmail.com. "Corresponding author. \\ ${ }^{2}$ Instituto Federal Catarinense (IFC), Concórdia, SC, Brasil. \\ ${ }^{3}$ Centro de Ciências Rurais, Universidade Federal de Santa Maria (UFSM), Santa Maria, RS, Brasil. \\ ${ }^{4}$ Instituto de Medicina Veterinária, Universidade Federal do Pará (UFPA), Castanhal, PA, Brasil.
} ABSTRACT: The purpose of this study was to assess the use of a homemade multiport for LESS (laparoendoscopic single-site surgery)
ovariohysterectomy (OVH) in cats. Intra and postoperative variables of the surgery steps, technical challenges, complications and evolution of
surgical time by a surgeon in training were evaluated. Twenty queens were selected for LESS OVH. The multiport device was manufactured of
a conical-shaped ethylene polytereftalate (PET) bottle, urethral catheter no. 8, latex balloon no. 11 , a 3.5mm and a 6mm laparoscopic trocars.
Hemostasis was carried out using bipolar diathermy. Mean total surgical time was $14.54 \pm 5.12$ minutes. Approach to right and left ovarian
pedicles and abdominal access for insertion of the multiport device were the most time consuming surgical steps. LESS ovariohysterectomy
using a new homemade multiport device is feasible and safe. Thus, the proposed technique may be considered as a minimally invasive
alternative to ovariohysterectomy in the feline specie.

Key words: $O V H$, single-port access, domestic felines, endosurgery.

Ovário-histerectomia por LESS em gatas com um novo multiportal artesanal

RESUMO: Objetivou-se avaliar o emprego do novo dispositivo multiportal artesanal para realização de ovariohisterectomia por LESS (cirurgia laparoendoscópica por único acesso) em gatas, analisando variáveis intraoperatórias de tempo cirúrgico das diferentes etapas que compõem o procedimento, suas possíveis dificuldades técnicas de execução e complicações trans e pós-operatórias. Avaliou-se ainda a curva de aprendizado deste procedimento, realizado por um cirurgião não proficiente na técnica. Vinte gatas foram submetidas à laparoscopia. Para a confecção do multiportal foi utilizado um recipiente de politereftalato de etileno (PET), uma sonda uretral $n^{\circ} 8$, um balão de látex $n^{\circ} 11$, um

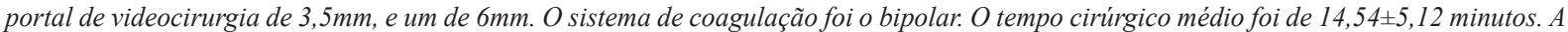
abordagem aos pediculos ovarianos direito e esquerdo e o acesso para introdução do portal foram as etapas que apresentaram maior tempo de execução. A OVH videoassistida empregando o novo dispositivo multiportal é factível, não demonstrando complicações. Acredita-se, portanto, que a técnica proposta torna-se uma alternativa para realização minimamente invasiva de ovariohisterectomia em felinos.

Palavras-chave: $O V H$, portal único, felinos domésticos, videocirurgia.

\section{INTRODUCTION}

Growing interest of researches regarding small animal surgical contraception is rising, especially regarding minimally invasive surgery (MIS). Variations on surgical technique are still one of the major interest in the veterinary surgery setting, such as minimally invasive ovariohysterectomy (OVH) (AGUIAR, 2011; BRUN, 2015). Several laparoscopic and laparoscopicassisted (lap-assisted) techniques were proposed.
Extensive variations in number and site of placement of ports, methods of hemostasis and comparison to conventional approach were reported (AGUIAR, 2011; SILVA et al., 2011; TAVARES et al., 2016).

Laparoscopic surgery has become more popular due to several advantages. Less tissue trauma, precise visceral handling, reduced bleeding, less postoperative pain and shorter convalescence and hospital stay are some of the most reported benefits of laparoscopy (DEVITT et al., 2005; VAN NIMWEGEN \& KIRPENSTEIJN, 2007). 
Single-port lap-assisted (SPLA) and LESS (laparoendoscopic single-site surgery) OVH are some of the techniques developed for surgical spay. Although, considered minimally invasive and of short time achievement, SPLA and LESS OVH present peculiar and challenging technical issues, such as lack of instrument triangulation. Those issues are particularly difficult even for experienced surgeons (GOWER \& MAYHEW, 2008; SILVA et al., 2011). Few studies regarding learning curve of laparoscopic or lap-assisted OVH were carried out on feline specie (TAVARES et al., 2016). Single-port access was sparsely reported in cats (KIM et al., 2011). Moreover, to the authors' knowledge, there is a gap in the literature regarding LESS access for feline spay. Commercially available multiport access devices require a $3-4 \mathrm{~cm}$ celiotomy (TAPIA-ARAYA et al., 2015), which make them not attractive for minimally invasive surgery in domestic cat.

Based on the lack of resources on single access surgery in the feline specie, the purpose of this study was to assess the first 20 cases of LESS OVH in cats, using a homemade polyethylene terephthalate (PET) and latex multiport, performed by a non-proficient surgeon.

\section{MATERIALS AND METHODS}

The multiport device was manufactured using a PET cone retrieved from an antiseptic solution bottle ${ }^{\mathrm{a}}$, a ring made of no. 8 urethral catheter ${ }^{\mathrm{b}}$, a no. 11 latex balloon ${ }^{c}$, a 3.5 and a $6 \mathrm{~mm}$ laparoscopic trocar, and a 2-0 USP nylon thread ${ }^{\mathrm{d}}$ (Figure 1A). The material were sterilized by 8 -hour immersion in $2 \%$ glutaraldehyde solution ${ }^{\mathrm{e}}$ prior surgery. The PET cone was first covered by the latex balloon (Figure 1B and C). A plastic ring manufactured of no. polyethylene sterile urethral catheter encircled the balloon opening (Figure 1D). Balloon sheath was then redirected towards the PET bottle opening, covering the opening along with the plastic ring (Figure 1E), creating a dome. The purpose of plastic ring was to insert it and to

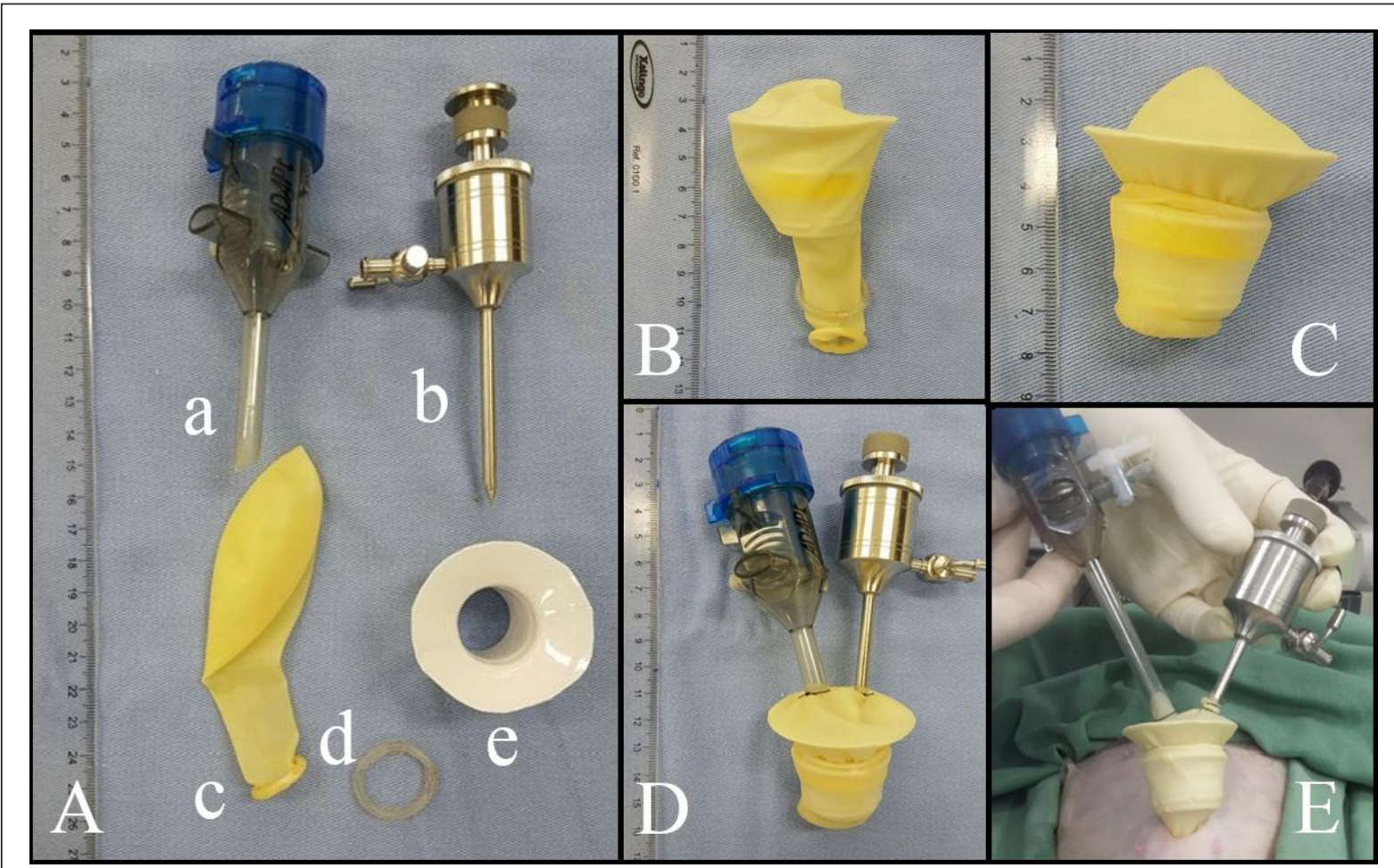

Figure 1 - Assembly of the homemade multiport access device for LESS ovariohysterectomy in queens. (A) Devices required, including (a) 6-mm trocar cannula, (b) 3.5-mm trocar, (c) latex balloon, (d) plastic ring made of a sterile polyethylene urethral catheter, and (e) polyethylene terephthalate (PET) cone taken from an antiseptic bottle. (B) PET cone covered by the no.11 latex balloon and plastic ring encircling the sheath of the balloon. (C) The sheath of the balloon covers the plastic ring and the shorter diameter of the cone, forming a dome. (D) Multiport properly prepared for use. (E) Intraoperative view of the homemade multiport inserted through the short celiotomy in a cat. Note the dome remains outside the abdominal cavity. Only the ring covered by the latex is inserted into the abdominal cavity, keeping the incision opening patent during surgery. 
fit the multiport device to the abdominal wall, while the lowest diameter of the PET cone would remain outside the abdominal cavity. Trocars were inserted through the latex in parallel assembly and attached using double surgeons' knot ligature at the largest diameter of the dome, with 2-0 USP nylon thread (Figure 1F), for telescope and instrument insertion. The portal was assembled prior to anesthesia induction.

For the study, 20 healthy mongrel queens, weighting $2.7 \pm 0.5 \mathrm{~kg}$ (range $1.8-3.5 \mathrm{~kg}$ ), mean age of $12 \pm 6$ months (range 6-25 months) admitted at a veterinary teaching hospital for spaying were used. Inclusion criteria was based on regularity on general physical and gynecological examination, complete blood count, total plasma protein, blood urea nitrogen, creatinine, alanine transaminase, alkaline phosphatase, gamma glutamyl transferase and serum albumin.

The cats undergone a 10-hour food fasting and perioperative abdomen clipping. A mixture of tiletamine-zolazepam ${ }^{\mathrm{f}}\left(5 \mathrm{mg} \mathrm{kg}^{-1}\right)$ and tramadol chloride $^{\mathrm{g}}\left(3 \mathrm{mg} \mathrm{kg}^{-1}, \mathrm{IM}\right)$ was given intramuscularly for premedication. General anesthesia was induced using propofol ${ }^{\mathrm{h}}\left(2 \mathrm{mg} \mathrm{kg}^{-1}\right.$ until loss of laryngeal reflex, IV) and maintained using isoflurane ${ }^{i}$ delivered in $100 \%$ oxygen, following tracheal intubation, in semi-open anesthesia system. Sodium cephalothin $\left(30 \mathrm{mg} \mathrm{kg}^{-1}\right)$ and meloxicam ${ }^{1}\left(0.1 \mathrm{mg} \mathrm{kg}^{-1}\right)$ were delivered intravenously for antibiotic prophylaxis and complementary perioperative analgesia, respectively. Additionally, epidural anesthesia was performed using lidocaine chloride ${ }^{\mathrm{m}}\left(4 \mathrm{mg} \mathrm{kg}^{-1}\right)$ and morphine sulfate $^{\mathrm{n}}\left(0.1 \mathrm{mg} \mathrm{kg}^{-1}\right)$. Cats were positioned in dorsal recumbency for routine aseptic prepare.

All surgeries were carried out by a nonproficient surgeon, without any training in basic laparoscopic skills. A $1.5-\mathrm{cm}$ celiotomy was carried out on the third quarter of the distance between the umbilicus and the cranial rim of the pubis. The ring of the multiport device was inserted into the abdominal cavity (Figure 1G). A multipurpose rigid telescope ${ }^{14}$ $\left(2.7 \mathrm{~mm}\right.$ in diameter, $30^{\circ}$ angle of view, coupled to a 3.3 protection sheath) was inserted through the

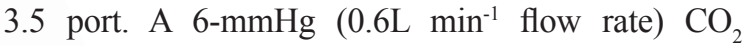
pneumoperitoneum was created.

For proper approach to the right ovarian pedicle (Figure 2A), the patient's chest was mildly rotated to the left, as previously described (SILVA, et al., 2011). A simultaneous bipolar coagulation and cut laparoscopic forceps ${ }^{\circ}$ (Lina Tripol Powerblade ${ }^{\mathrm{TM}}$, $5.5 \mathrm{~mm}$ and $30 \mathrm{~cm}$ in length) was inserted through the 6-mm port for both grasping and coagulation. Afterwards, the right uterine horn was grasped and raised to the abdominal wall level for tacking suture using 0 USP nylon thread. Right ovarian pedicle was coagulated and transected. Same approach was used for the left ovarian pedicle (Figure 2B). Next, the left uterine horn was released, grasped and pulled into the dome. The multiport device was retrieved from the abdominal wall by gentle traction, allowing uterine body exposition and pneumoperitoneum drainage (Figure 2C). Uterine vessels and body were coagulated and transected slightly cranial to the cérvix, using the same laparoscopic forceps (Figure 2D). Uterine stump was inspected for bleeding and replaced into the abdominal cavity.

The linea alba was sutured in cross mattress pattern and subcutaneous space was closed in simple interrupted inverting pattern, both using 2-0 USP polyglecaprone $25^{\mathrm{p}}$ thread. Skin was closed with a horizontal mattress suture, using 4-0 USP nylon thread (Figure 2E).

Postoperative care included sodium dipyrone $^{\mathrm{q}}\left(15 \mathrm{mg} \mathrm{kg}^{-1}\right.$, PO, b.i.d, for three days) and meloxicam $\left(0.1 \mathrm{mg} \mathrm{kg}^{-1}\right.$, PO, single dose) for analgesia, wound cleansing with sterile normal saline twice a day, and use of wound abdominal protection clothes until suture retrieval, on the $10^{\text {th }}$ day postop. Patients were discharged following 24 hours of surgery.

For assessing evolution of operative time by a non-proficient surgeon, surgeries were distributed in four groups (I, II, III and IV) of five consecutive procedures. Surgeries were divided into five intraoperative steps: (a) access to the abdominal cavity: time elapsed from skin incision to insertion of the multiport device; (b) right pedicle: from grasping the uterine horn to transection of the pedicle; (c) left pedicle: the same as for approaching the right pedicle; (d) uterine body: time elapsed between exteriorization of the uterus and replacement of the stump into the abdomen; and (e) synthesis: time spent from closing the linea alba to skin suture. At the end of surgery, total volume of $\mathrm{CO}_{2}$ spent was recorded.

Operative time was compared among groups of five surgeries, and among intraoperative steps regardless of group, using one-way ANOVA and Bonferroni's post hoc test for comparison in pairs, if $\mathrm{P}<0.05$. Complications and surgical difficulties would be assessed descriptively, if present.

\section{RESULTS AND DISCUSSION}

A non-proficient surgeon safely achieved LESS-OVH with the homemade PET multiport. Procedure was easily carried out, in reduced operative time and relatively inexpensive (estimate cost $\mathrm{R} \$ 0.40$ to assembly the multiport device). Mean overall surgical time was $14.5( \pm 5.12)$ minutes (range 8.1-27.5 


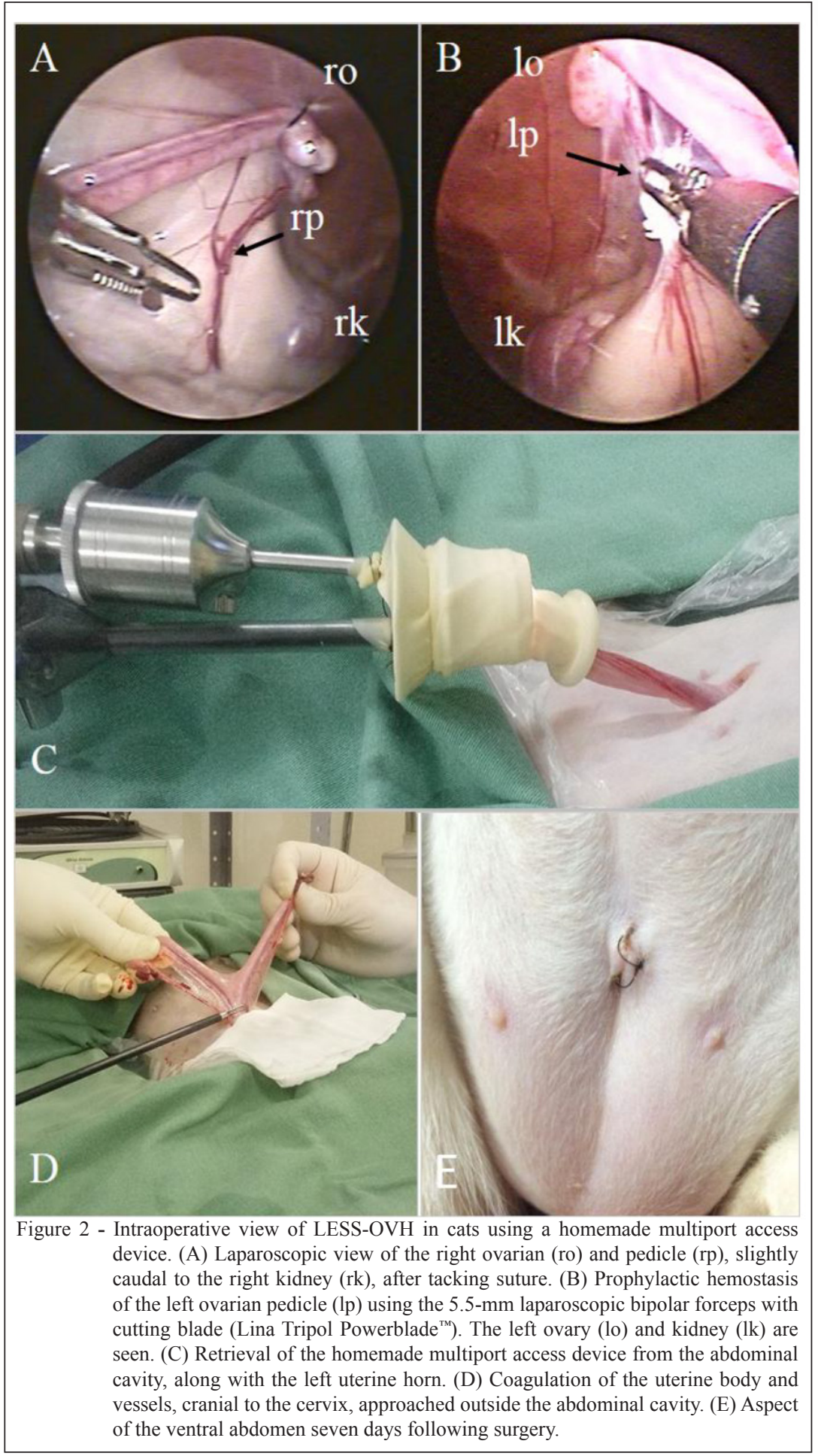

minutes) regardless of group. Mean anesthesia time was $20.52( \pm 7.13)$ minutes. These results were shorter than those reported for two-port (FERREIRA et al., 2011) and three-port (SCHIOCHET et al., 2009) lap- assisted (55 and 81.11 minutes, respectively) and for open OVH (25.6 minutes) in queens (SCHIOCHET, 2014). This might have occurred due to the use of the homemade multiport. The multiport device 
provided quick and optimal access to the abdominal cavity by open approach. Moreover, the multipurpose laparoscopic forceps allowed grasping, dissecting, coagulation and transection without need for instrument change. Multiple puncture and instrument change are time-consuming issues in lap-spays in small animals (MALM, 2004; SCHIOCHET et al, 2009).

Mean operative time differed among groups of five consecutive procedures $(\mathrm{P}=0.008$; Table 1$)$. Mean surgery time was longer in the first group of surgeries (group I; $21 \pm 5.8$ minutes) than in groups II (14.3 \pm 1.4 minutes; $\mathrm{P}<0.05)$, III $(11.8 \pm 2.5$ minutes; $\mathrm{P}<0.01)$ and IV $(10.9 \pm 1.6$ minutes; $\mathrm{P}<0.01)$. Lapassisted approach allows achieving complex surgeries, while keeping the essentials of MIS. The LESS$\mathrm{OVH}$ technique presented in this study fulfills those fundamentals. Lap-assisted procedures mixes intra and extracorporeal steps, making them both effective and dynamic (FREEMAN, 1999; DEVITT et al., 2005; SILVA et al., 2011). Such approach dramatically reduces complexity of MIS spays. In the authors' opinion, $30^{\circ}$ telescope provided optimal field of view and minimized surgeon's distress due to parallelism between telescope and instrument. However, for nontrained surgeons, $30^{\circ}$ telescope may be disturbing (BRUN, 2015). For single-port spay, $0^{\circ}$ operative telescope provided limited view of the pedicles and no instrument triangulation (MOTTIN, 2014).

Regardless of group, time for approaching the uterine body (step d) was markedly shorter than the others $(\mathrm{P}<0.0001)$. There was no difference among time to accomplish the other steps (Table 2). Other study reported longer time to approach the left (8.2 minutes) and right (7.7 minutes) ovarian pedicles in bitches (SILVA el al., 2011). Other trial revealed hemostasis of ovarian pedicles and uterine body as most time consuming and challenging steps of laparoscopic OVH in bitches (MALM et al., 2004). The authors stated those limitations were closely related to learning curve. Definitively, lap-assisted spays seems to be more versatile and less technically demanding than three-port, four-port, hybrid-NOTES (natural orifice transluminal endoscopic surgery) and total-NOTES (FREEMAN et al., 2009; BRUN, 2015).

There were no complications in this trial. Small incision length $(1.5 \mathrm{~cm})$ and optimal sealing against leakage (by accurate coupling of the multiport device to the incision), besides proper use of bipolar diathermy were crucial issues for reaching those results. Complications such as hemorrhage, subcutaneous emphysema, hematomas and dehiscence were reported following multiple-puncture lap-assisted $\mathrm{OVH}$ in queens (SCHIOCHET et al., 2009; TAVARES et al., 2016).

Need for replacement of the multiport device in one patient was the only distressful event reported in this study. Plastic ring was not completely inserted into the abdomen, which was promptly replaced. In fact, surgical time was not substantially affected (17 minutes). Laparoscopic skills develops as learning curve progresses, which varies according type and number of procedures (TAVARES et al., 2016). Thus, practicing on a daily basis is essential for reaching the edge of the learning curve in MIS (MENON et al., 2002).

The $6 \mathrm{mmHg}$ intra-abdominal pressure (IAP) and $0.6 \mathrm{~L} \mathrm{~min} \mathrm{~min}^{-1}$ insufflation rate provided both optimal field of view and safe organ handling. Moreover, no evidence of cardiorespiratory distress was observed at any time point during pneumoperitoneum. The authors believe irrelevant hemodynamic changes may occur in cats using low-pressure pneumoperitoneum. However, further studies should fill this gap in the current literature. IAP of $8-12 \mathrm{mmHg}$ may not cause distress in healthy adult patients, while $6-8 \mathrm{mmHg}$ is indicated for puppies. IAP above $15 \mathrm{mmHg}$ should be avoided (BRUN, 2015).

Table 1 - Comparison of groups of five consecutive surgeries, performed by a non-proficient surgeon in four different moments (I-IV) of learning process of LESS ovariohysterectomy in cats, using a new homemade multiport device.

\begin{tabular}{lcccc}
\hline & & & & \\
Surgeries & I & II & III & \\
\cline { 2 - 5 } 1 & 27.45 & 15.45 & 14.45 & \\
2 & 27.55 & 13.23 & 13.90 & IV \\
3 & 16.8 & 15.30 & 11.25 & 11.75 \\
4 & 17.1 & 15.45 & 8.16 & 12.75 \\
5 & 16.47 & 12.42 & 11.16 & 11.50 \\
Mean $( \pm \mathrm{SD})$ & $21.07( \pm 5.87)^{*}$ & $14.37( \pm 1.44)$ & $11.78( \pm 2.51)$ & $10.93( \pm 1.57)$ \\
\hline
\end{tabular}

${ }^{*} \mathrm{P}<0.05 . \mathrm{SD}$ : standard deviation. 
Table 2 - Time of execution of intraoperative steps of LESS ovariohysterectomy in queens, using a homemade polyethylene terephthalate and latex multiport access device, performed by a non-proficient surgeon.

\begin{tabular}{|c|c|c|c|c|c|c|}
\hline \multirow[b]{3}{*}{ Mean \pm SD } & \multirow{3}{*}{ Abdominal access } & \multirow{3}{*}{$\begin{array}{c}\text { Right pedicle } \\
2.6 \pm 1.1^{\mathrm{a}}\end{array}$} & \multirow{3}{*}{$\begin{array}{c}\text { Left pedicle } \\
2.1 \pm 1.1^{\mathrm{a}}\end{array}$} & \multirow{3}{*}{$\begin{array}{c}\text { Uterine body } \\
0.6 \pm 0.3^{\mathrm{b}}\end{array}$} & \multirow{3}{*}{$\begin{array}{c}\text { Abdominal synthesis } \\
2.0 \pm 0.5^{\mathrm{a}}\end{array}$} & \multirow{3}{*}{$\begin{array}{c}\text { Overall time } \\
14.5 \pm 5.1\end{array}$} \\
\hline & & & & & & \\
\hline & & & & & & \\
\hline Minimum & 1.2 & 1.0 & 0.8 & 0.2 & 1.2 & 8.2 \\
\hline Maximum & 5.2 & 5.2 & 4.8 & 1.7 & 3.0 & 27.5 \\
\hline VC (\%) & 39.9 & 48.0 & 50.2 & 52.9 & 25.8 & 35.2 \\
\hline
\end{tabular}

Different letters represent $\mathrm{P}<0.0001$. SD: standard deviation; VC: variation coefficient in percentile.

No substantial $\mathrm{CO}_{2}$ leakage was noted using the handmade multiport assessed in this study. Pneumoperitoneum remained constant during surgeries. Mean $\mathrm{CO}_{2}$ volume spent for creating and maintaining pneumoperitoneum was $3.3 \pm 1.8 \mathrm{~L}$. Optimal coupling to the incision, no instrument change and short surgery time comprised potential causes for such outcome. Other studies reported use of 64 and 51L of $\mathrm{CO}_{2}$ during two-port lap-assisted $\mathrm{OVH}$ in cats, using monopolar and bipolar diathermy, respectively (AGUIAR, 2011). It is truly believed that some factors may affect $\mathrm{CO}_{2}$ consumption during laparoscopic surgery, such as the use of multiple punctures, need for several instrument changes and surgical time. However, none of those issues were reported in this study.

To the authors' concern, there were no reports of LESS approach in the feline specie. This gap may border on the fact that there is no multiport device commercially available with proper dimensions for use in cats. Most LESS access devices currently available require approximately $3-4 \mathrm{~cm}$ incision length for perfect match to the abdominal wall (TAPIA-ARAYA et al., 2015), which seems to be particularly disadvantageous to use in cats.

In the authors' opinion, the main limitation of the proposed technique is reaching sterilization. Chemical sterilization is becoming more restrict worldwide and should be substituted by other methods. As most compounds on the multiport device are thermosensitive, probably the best sterilization method should be ethylene oxide or hydrogen peroxide immersion in chemical solutions. Enlarged uterus, such as pyometra and tumors, may not be adequate to be operated using the proposed technique, requiring incision enlargement. However, those hypotheses should be further investigated. Although, this study contributed for the establishment of a new surgical OVH technique in cats, LESS$\mathrm{OVH}$ technique should be tested to other traditional open and laparoscopic-assisted technique regarding surgical trauma, hematological variables, stress and postoperative pain before its prior routine use.

\section{CONCLUSION}

LESS-OVH using a homemade PET/latex multiport device was both efficient and safe. Further studies on pain and postoperative recovery may warrant LESS-OVH using a homemade multiport device as a further option for MIS spay in cats.

\section{AKNOWLEDGEMENT}

The authors would like to thank Mrs. Vilma Peixeiro and WEM Equipamentos Eletrônicos Ltda. for providing Lina Tripol Powerblade ${ }^{\text {TM }}$ used in this study, and Conselho Nacional de Desenvolvimento Científico e Tecnológico $(\mathrm{CNPq})$ for financial support and for providing resources to achieve this and other studies (process no. 460892/2014-2).

\section{SOURCE AND MANUFACTURERS}

a - Riohex ${ }^{\mathrm{TM}}$ 2\% Degermante, Rioquímica Ind. Farm. Ltda., São José do Rio Preto, SP.

b - Sonda uretral $n^{\circ} 8$, Embramed Ltda., São Paulo, SP.

c - Balões de látex transparentes 11", Globotex Ltda., São Paulo, SP. d - Nylon Shalon, Shalon Medical Ltda., Goiânia, GO.

e - Glutaron ${ }^{\mathrm{TM}} 2 \%$, Rioquímica Ind. Farm. Ltda., São José do Rio Preto, SP.

e - Zoletil ${ }^{\mathrm{TM}}$ 50, Virbac Saúde Animal Ltda., São Paulo, SP.

f - Cloridrato de tramadol inj. 50mg, Hipolabor Farmacêutica Ltda., Belo Horizonte, MG.

g - Propovan ${ }^{\mathrm{TM}}$, Cristália Inf. Farm. Ltda., Itapira, SP.

h - Isoforine ${ }^{\mathrm{TM}}$, Cristália Inf. Farm. Ltda., Itapira, SP.

i - Cefalotina sódica inj. 2g, Hipolabor Farmacêutica Ltda., Belo Horizonte, MG.

j - Maxicam ${ }^{\text {TM }} 2 \%$, Ourofino Saúde Animal Ltda., Cravinhos, SP.

1 - Cloridrato de lidocaína inj. 2\%, Hipolabor Farmacêutica Ltda., Belo Horizonte, MG.

m - Sulfato de morfina inj. 10mg, Hipolabor Farmacêutica Ltda., Belo Horizonte, MG. 
n - 64029 BA HOPKINS ${ }^{\text {TM }} 30^{\circ}$ Telescope, Karl Storz ${ }^{\mathrm{TM}}$, H. Strattner Ltda., São Paulo, SP.

o - Lina Tripol Powerblde ${ }^{\mathrm{TM}}$ 5mm, Lina Medical, WEM Eq. Eletr. Ltda, Ribeirão Preto, SP.

p-Caprofyl ${ }^{\mathrm{TM}}$, Ethicon, Johnson \& Johnson do Brasil Ltda., São Paulo, SP. q - Dipirona gotas 500mg, Teuto Ind. Farm. Ltda., Anápolis, GO.

\section{BIOETHICS AND BIOSSECURITY COMMITTEE APPROVAL}

This study was performed following approval by the Comissão de Ética no uso de Animais da Universidade de Passo Fundo (CEUA-UPF protocol 036/2016).

\section{REFERENCES}

AGUIAR, J. Eletrocoagulação bipolar e monopolar na ovariosalpingohisterectomia videocirurgica híbrida utilizando dois portais em felinos hígidos. 2011. 59f. Thesis (Master's Degree) Ciências Veterinárias, Universidade Federal do Rio Grande do Sul, RS.

BRUN, M.V. Cirurgias do aparelho reprodutor feminino de caninos. In: . Videocirurgia em pequenos animais. Rio de Janeiro: Roca, 2015. p.186-213.

DEVITT, C.M. et al. Duration, complications, stress, and pain of open ovariohysterectomy versus a simple method of laparoscopicassisted ovariohysterectomy in dogs. Journal of the American Veterinary Medical Association, v.227, n.6, p.921-927, 2005. Available from: <https://www.avma.org/News/Journals/Collections/ Documents/javma_227_6_921.pdf >. Accessed: Nov. 18, 2016.

FERREIRA,M.P. etal. Ovário-salpingo-histerectomia videolaparoscópica em gatos domésticos: técnica com dois portais. Acta Scientiae Veterinariae, v.39, n.4, Pub.997, p.1-4, 2011. Available from: <http:// www.ufrgs.br/actavet/39-4/PUB\%20997.pdf $>$. Accessed: Nov. 18, 2016.

FREEMAN, L.J. et al. Comparison of pain and postoperative stress in dogs undergoing natural orifice transluminal endoscopic surgery, laparoscopic, and open oophorectomy. Gastrointestinal Endoscopy, v.72, n.2, p.373-380, 2009. Available from: <http://www.giejournal. org/article/S0016-5107(10)00139-2/pdf>. Accessed: Nov. 18, 2016.

FREEMAN, L.J. Veterinary endosurgery. Saint Louis: Mosby, 1999. 276p.

GOWER, S.; MAYHEW, P. Canine laparoscopic and laparoscopicassisted ovariohysterectomy and ovariectomy. Compendium Continuing Education for Practicing Veterinarians, v.30, n. 8 , p.430-439, 2008. Available from: <https://www.ncbi.nlm.nih.gov/ pubmed/18833541>. Accessed: Nov. 18, 2016.

KIM Y.K. et al. Feasibility of single-portal access laparoscopic ovariectomy in 17 cats. Veterinary Record, v.169, n.7 p.179, 2011.
Available from: <http://veterinaryrecord.bmj.com/content/169/7/179. full.pdf>. Accessed: Nov. 18, 2016. doi: 10.1136/vr.d4293.

MALM, C. et al. Ovário-histerectomia: estudo experimental comparativo entre as abordagens laparoscópica e aberta na espécie canina. Intraoperatório-I. Arquivo Brasileiro de Medicina Veterinária e Zootecnia, v.56, n.4, p.457-466, 2004. Available from: <http:/www.scielo.br/pdf/ abmvz/v56n4/21982.pdf>. Accessed: Nov. 18, 2016.

MENON, M. et al. Laparoscopic and robot assisted radical prostatectomy: estabilishment of a structured program and preliminary analysis of outcomes. Journal Urology, v.168, n.3, p.945-949, 2002. Available from: <http://www.sciencedirect.com/science/article/pii/ S002253470564548X>. Accessed: Nov. 18, 2016. doi: 10.1097/01. ju.0000023660.10494.7d.

MOTTIN, T.S. Ovariohisterectomia videolaparoscópica hibrida por acesso único e por dois portais em cadelas com até $10 \mathrm{~kg}$ de peso corporal. 2014. 72f. Thesis (Master's Degree) - Ciências Veterinárias, Universidade Federal do Rio Grande do Sul, RS.

SCHIOCHET, F. Ovariosalpingohisterectomia em felinos hígidos: comparação entre as técnicas laparoscópica, laparoscópica híbrida e convencional. 2014. 152f. Thesis (Doctor's Degree) - Ciências Veterinárias, Universidade Federal do Rio Grande do Sul, RS.

SCHIOCHET, F. et al. Ovário-histerectomia laparoscópica em felinos hígidos: estudo comparativo de três métodos de hemostasia. Arquivo Brasileiro de Medicina Veterinária e Zootecnia, v.61, n.2, p.369-377, 2009. Available from: <http://www.scielo.br/pdf/ abmvz/v61n2/a13v61n2.pd>. Accessed: Ago. 30, 2017.

SILVA, M.A.M. et al. Single-port video-assisted ovariohysterectomy in bitches: retrospective study of 20 cases. Ciência Rural, v.41, n.2, p.294-300, 2011. Available from: <http://www.scielo.br/ scielo.php?script $=$ sci_arttext\&pid $=$ S0103-84782011000200019 $>$. Accessed: Nov. 18, 2016. doi: 10.1590/S0103-84782011005000013.

TAPIA-ARAYA, A.E. et al. Laparoscopic ovariectomy in dogs: comparison between laparoendoscopic single-site and three-portal access. Journal of Veterinary Science, v.16, n.4, p.525-530, 2015. Available from: $<\mathrm{https}: / /$ www.ncbi.nlm.nih.gov/pmc/articles/PMC4701746/pdf/jvs-16-525.pdfs. Accessed: Nov. 18, 2016. doi: 10.4142/jvs.2015.16.4.525.

TAVARES, D.C. et al. Video-assisted ovariohysterectomy in domestic cats (Felis catus, Linnaeus, 1758) using two access portals. Acta Cirurgica Brasileira, v.31, n.2, p.84-91, 2016. Available from: $<$ http://www.scielo.br/scielo.php?script=sci arttext\&pid=S010286502016000200084\&lng=en\&nrm=iso>. Accessed: Nov. 18, 2016. doi: $10.1590 / \mathrm{S} 0102-865020160020000002$.

VAN NIMWEGEN, S.A.; KIRPENSTEIJN, J. Comparison of Nd:YAG surgical laser and remorgida bipolar electrosurgery forceps for canine laparoscopic ovariectomy. Veterinary Surgery, v.36, p.533-540, 2007. Available from: <https://www.ncbi.nlm.nih.gov/pubmed/17686126>. Accessed: Nov. 18, 2016. doi: 10.1111/j.1532-950X.2007.00304.x. 